\title{
The Inhibitory Effect of Some Natural Bioactive D-Glucopyranoside Derivatives against SARS- CoV-2 Main Protease (Mpro) and Spike Protease (Spro)
}

\author{
Ajoy Kumer ${ }^{1}$, Unesco Chakma ${ }^{2}$ and Sarkar Mohammad Abe Kawsar3* \\ ${ }^{1}$ Department of Chemistry, European University of Bangladesh, Gabtoli, Dhaka-1216, Bangladesh \\ ${ }^{2}$ Department of Electrical and Electronics Engineering, European University of Bangladesh, Gabtoli, Dhaka-1216, \\ Bangladesh \\ ${ }^{3}$ Laboratory of Carbohydrate and Nucleoside Chemistry (LCNC), Department of Chemistry, Faculty of Science,
} University of Chittagong, Chittagong, Bangladesh

\begin{abstract}
Outbreak of coronavirus seems to have exacerbated across the globe, but drugs have not been discovered till now. Due to having the antiviral activity of D-glucopyranoside derivatives, this study was designed to examine as the inhibitor by in sillico study against the main protease (Mpro) and Spike protease (Spro) of SARS-CoV-2. First, these derivatives were optimised by Density Functional Theory (DFT). The observation of this study was monitored by molecular docking tools calculating the binding affinities. Afterwards, the ligand interaction with protein was accounted for selecting the how to bind of active sites of the protein. Next, the root means square deviation (RMSD) and root mean square fluctuation (RMSF) were illustrated for determining the stability of the docked complex. Finally, AMDET properties were calculated as well as the Lipisinki rule. All of the derivates showed a binding affinity more than $-6.0 \mathrm{kcal} / \mathrm{mol}$ while derivatives $\mathbf{2}, \mathbf{3}$, and 9 were the best-bonded scoring inhibitor against $\mathrm{M}^{\text {pro }}$ and Spro. In addition, the chemical descriptors were more supportive tools as an inhibitor, and the Lipisinki rule was satisfied for maximum molecules as a drug. Besides, D-glucopyranoside derivatives may be predicted that they are non-carcinogenic and low toxic for both aquatic and non-aquatic species.
\end{abstract}

Keywords: glucopyranoside; SARS-CoV-2; docking; molecular dynamic; ADMET

\section{INTRODUCTION}

The quick-tempered enlargement of glycobiology was strained meticulous attention to complex carbohydrate molecules, a class of natural compounds and poly-functional organic molecules which play a significant biological role in the living body (Kobata et. al., 1993; Nakamura et al., 2008), as well as the human body (Lee et. al., 1995; Lee et al., 2019). Carbohydrates are originated in all living organisms having many vital biological functions (Weymouth-Wilson et. al., 1997; Guillen et al., 2010). In living cells, carbohydrate, ribose, is the crucial part by which nucleic acids (RNA and DNA) were composed containing the genetically characteristic (Roberts et al., 1992). Besides, the vital biological function in the human body, it has vast applications as coenzymes (Meegalla et al., 2002), antibiotics (Ritter et al., 2001), antibacterial agents (Abel et al., 2002), antifungal agents (AlFindee et al., 2018) anticancer potential drugs (Hartinger et al., 2008), antiviral agent (Van der Meer et al., 2007) specific nutritional actions (Hemre et al., 2002), gastric acidity (Lennard-Jones et al., 1968), hydrolysis by mammalian enzymes (Glock et al., 1954), gastrointestinal absorption (Eliasson et al., 1995), ingredients, and additives of food products (Zeller et al., 1998), anti-inflammatory activity (Ogundajo et al., 2018) 
and toxins (Kitov et al., 2000). Most of these were produced in the plant's body by photosynthesis as natural sources, acyl glycoses, glucopyranoside, and acyl glycosides.

As D-glucopyranoside and its derivatives were estimated the antimicrobial activity, it is the new avenue to the study after heteroatom modification in carbohydrates. Moreover, it was obtained that some molecules of D-glucopyranosides were used as potential antiviral inhibitors against coxsackievirus B3 (Zhu et al., 2009), Anti-HIV-1 activity and type 1 virus (HSV-1) (Kondratenko et al., 2004), mice infected with influenza virus (Liu et al., 2017), acute lung injury in mice (Niu et al., 2015) and SARS-coronavirus (Hoever et. al., 2005; Pompei et al., 2009). Even the (+)-pinoresinol-O- $\beta$-D-glucopyranoside was reported by $\mathrm{L}$. Li et al. (2019) as the antiviral potential drugs of influenza A (H1N1) virus infection (Li et al., 2019). However, it must be concluded that the derivatives of both $\alpha$ - and $\beta$ D-glucopyranoside conveyed the antivirus potential molecules. As a result, methyl 4,6-O-benzylidene- $\alpha-\mathrm{D}-$ glucopyranoside and its derivatives have been selected by in sillico study for evaluating antiviral activity against SARS$\mathrm{CoV}-2$, as well as quantum calculation. The selected methyl 4,6-O-benzylidene- $\alpha$-D-glucopyranoside and its derivatives were synthesised by Kawser et al. (2013) (Kawser et al., 2013) and other researchers also synthesised these molecules (Farhana et. al., 2021; Kaszynska et. al., 2012; Kawser et. al., 2014; Mirajul et al., 2019).

After genomic and phenotypic structure analysis of SARS$\mathrm{CoV}-2$, it was found that the SARS-CoV-2 consisted of five layers with protein, such as spike protease (Spro), Nucleocapsid protein ( ${ }^{\text {pro }}$ ), Membrane protease (MB ${ }^{\text {pro }}$ ), Envelope (Ero), and RNA viral protease ( $\left.\mathrm{R}^{\mathrm{pro}}\right)$. The most outer part is constituted by Spro which is attached to the host body in the initial stage and passed information in $\mathbf{M}^{\text {pro. }}$ Now, it was exploited that the main protease(Mpro) strain of SARS-CoV-2 is a single-stranded with a positive-sense RNA genome, sub-family Coronavirinae in the family Coronaviridae and the order Nidovirales, which is the similar genome of Mouse Hepatitis Virus (MHV) (Miura et al., 2008) SARS-CoV-2, SARS-CoV-1, and MERS-CoV (Mousavizadeh et al., 2021). The first layer of SARS-CoV-2 is Spro which is connected with Npro which as well is connected with MBpro and Epro. The chemical and physiological activity of SARS-CoV-2 has been performed by RNA and a nucleocapsid protein which is known as are main protease. In general, there are two types of polypeptides for the main protease, which are classified according to their length, and consist of chymotrypsin-like protease (3CL ${ }^{\text {pro }}$ ) or main protease (Mpro). Though three or four types of abundant viral proteins are obtained in $\mathrm{CoV}-19$, the membrane glycoprotein is most common whereas the short unique $\mathrm{N}$-terminal fragment is connected with the spike protein (outside), and a long - $\mathrm{COOH}$ terminus is added with the virion (inside) (De Haan et al., 1998).

\section{MATERIALS AND METHOD}

\section{A. Preparation of Ligand and Calculation of Chemical Reactivity and Descriptors}

The Material Studio 8.o was used for geometry optimisation for ten natural bioactive D-glucopyranoside and its derivatives (Ramos et al., 2020). For the optimisation, basis set. or functional, B3LYP of DMol code was used and calculated the chemical reactivity indicators using frequency calculation by DFT functional (Pearson et al., 1986). After optimisation, the molecular frontier orbitals diagram of HOMO and LUMO was redesigned with analysis tools. Finally, the electrostatic potential map was taken from the analysis tools.

\section{B. Methods for Molecular Docking}

The starting three-dimensional (3D) structure of Mpro of coronavirus disease (CoV-19) was collected from Protein Data Bank (PDB) with ID: 5r7y, following link: https://www.rcsb.org/structure/5r7y. Moreover, the spike protease (6xs6) was taken from PDB with the link: https://www.rcsb.org/structure/6XS6 (Yurkovetskiy et al., 2020). It was viewed by the Pymol software version using PyMOL V2.3 (https://pymol.org/2/) (Delano et al., 2002). All water molecules and unexpected ligands or heteroatoms were removed to get fresh protein, and it was saved as PDB files. Both protein and drug PDB files were uploaded in PyRx software for molecular docking as the auto dock vina. After the molecular docking, the docked complex was taken Discovery Studio version 2017 for result analysis and view (Inc et al., 2013). 


\section{Determination of the Data of ADMET}

The ADMET properties were accumulated by the online database amdetSar, http://lmmd.ecust.edu.cn/admetsar2, which has been established as the most acceptable database for predicting the AMDET parameters (Cheng et. al., 2012; Hongbin et. al., 2018; Phillips et al., 2020).

\section{Molecular Dynamic}

Performing MD simulations of the top three according to docking score, NAMD software was employed using run interactively with live view on high configuration laptop computer (Phillips et al., 2020). MD simulation was devoted to underpinning the docking results gained for the best ligand-CoV-19 protein interaction up to 5000 ps for holoform (drug-protein) applying AMBER14 force field (Skjevik et al., 2015). In the presence of a water solvent, the total system was equilibrated with $0.9 \% \mathrm{NaCl}$ at $298 \mathrm{~K}$ temperature. A cubic cell was propagated within $20 \AA$ on every side of the process and periodic boundary circumstances during the simulation. After simulation, the RMSD and RMSF were analysed using the VMD software.

\section{E. Statistical Analysis}

For each framework studied, experimental observations were displayed as mean \pm standard error for three replicates.

\section{RESULT AND DISCUSSION}

\section{A. Optimised Structure}

The ten natural bioactive D-glucopyranoside and its derivatives were simulated for geometry optimisation by computational tools through the DFT method, and the optimised chemical structures of these derivatives are listed in (Figure 1) with molecular code.

\section{B. HOMO LUMO, and Chemical Reactivity Descriptors}

The computed ELUMO, EHOMO and $\Delta \mathrm{E}$ gap, chemical potential $(\mu)$, electronegativity $(\chi)$, hardness $(\eta)$, softness (s) and electrophilicity $(\omega)$ of natural bioactive Dglucopyranoside and its derivatives are presented in Table 1. These data have been calculated by the B3LYP functional of DFT code. The HOMO LUMO energy gap was used to calculate chemical potential which has a variable value around -4.569 to -5.284 . Moreover, the HOMO LUMO energy gap mentions the high kinetic and low chemical stability (Alam et. al., 2021; Ajoy et. al., 2021; Kawsar et. al., 2020; Nuruzzaman et. al., 2019; Maowa et. al., 2021; Ajoy et al., 2019). From Table 1, it was found that the HOMO LUMO gap is about 6.760 to $8.808 \mathrm{eV}$ for all tested drugs while derivatives $\mathbf{2}$ and $\mathbf{9}$ showed the lowest energy gap as well as having the largest softness value (Maowa et. al., 2021; Islam et. al., 2020; Bulbul et al., 2021). The frontier molecular orbital (FMO) has determined the chemical reactivity and active sites for any drugs. The larger magnitude of LUMO indicates the higher binding affinity to the protein of SARS-CoV-2. The lower magnitude of the energy gap contributes to forming an interaction with SARSCoV-2 protein with drugs. From Figure 2, the FMOs have been presented with HOMO and LUMO by indicating various colours. In the case of LUMO, the pink colour indicates the negative node and the Dark Lemon colour indicates the positive node of orbitals. On the other hand, the yellow colour for HOMO indicates a positive node of orbital, and the light greenish colour expresses the negative node of orbitals. It must be written that the protein can be attached to the part of LUMO. It could be said the HOMO was caught in benzene rings due to having pi electrons which leads to this pi-electron delocalisation. On the contrary, the LUMO was obtained in the glycosides ring. Due to having various hydroxyl groups and oxygen atom in this ring lead the electron lacking as LUMO which makes the binding affinity with protein. 


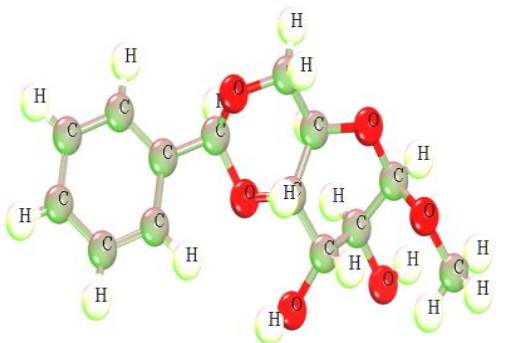

Methyl 4, 6-O-benzylidene- $\alpha-\mathrm{D}-$ glucopyranoside (1)

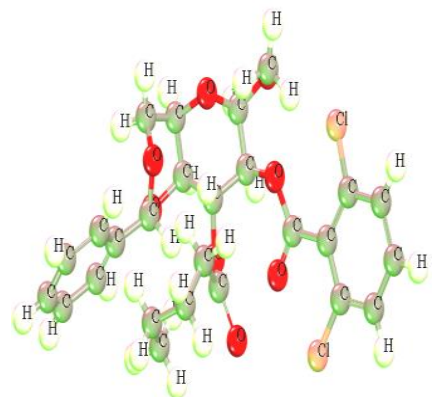

Methyl 4,6-O-benzylidene-2-O-(2,6dichlorobenzoyl)-3-O-pentanoyl- $\alpha-\mathrm{D}$ glucopyranoside (4)

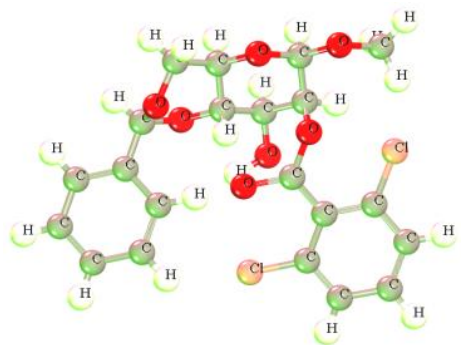

Methyl 4,6-O-benzylidene-2-O-(2,6dichlorobenzoyl)- $\alpha$-D-glucopyranoside

(2)

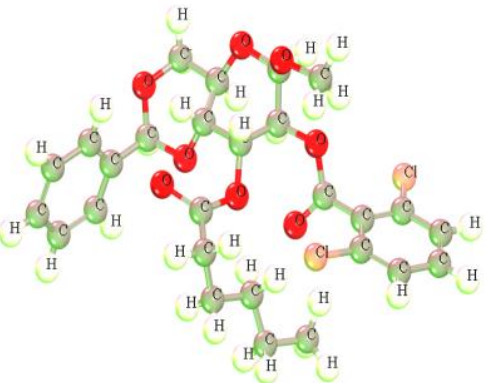

Methyl 4,6-O-benzylidene-2-O-(2,6dichlorobenzoyl)-3-O-hexanoyl- $\alpha-\mathrm{D}-$ glucopyranoside (5)

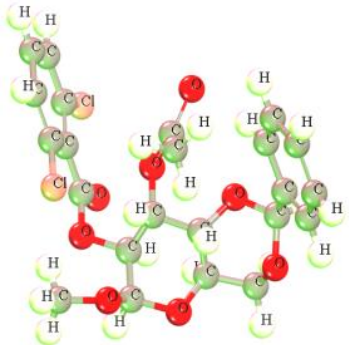

Methyl 3-O-acetyl-4,6-Obenzylidene-2-O-(2,6dichlorobenzoyl)- $\alpha-\mathrm{D}$ glucopyranoside (3)

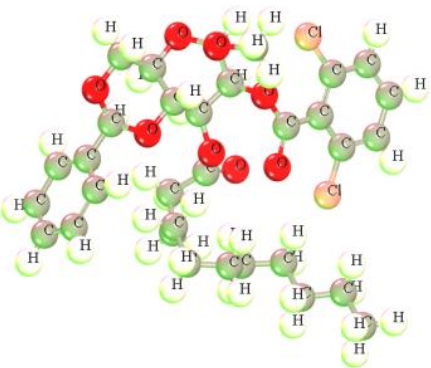

Methyl 4,6-O-benzylidene-2-O(2,6-dichlorobenzoyl)-3-O-lauroyla-D-glucopyranoside (6)

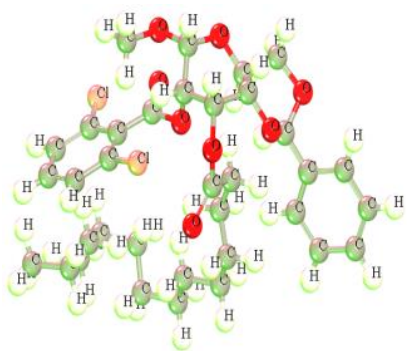

Methyl 4,6-O-benzylidene2-O-(2,6-dichlorobenzoyl)3-O-myristoyl- $\alpha-\mathrm{D}-$ glucopyranoside (7)

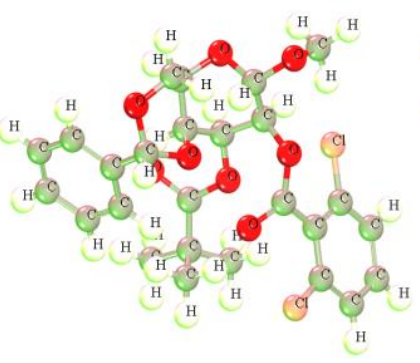

Methyl 4,6-O-benzylidene2-O-(2,6-dichlorobenzoyl)3-O-pivaloyl- $\alpha-\mathrm{D}$ glucopyranoside (8)

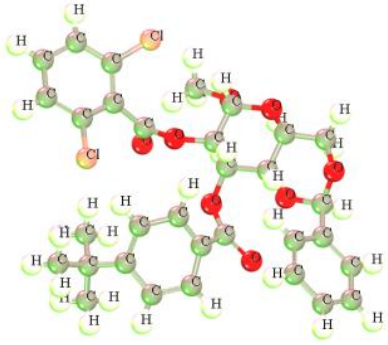

Methyl 4,6-O-benzylidene2-O-(2,6-dichlorobenzoyl)3-O-(4-t-butylbenzoyl)- $\alpha$ -

D-glucopyranoside (9)

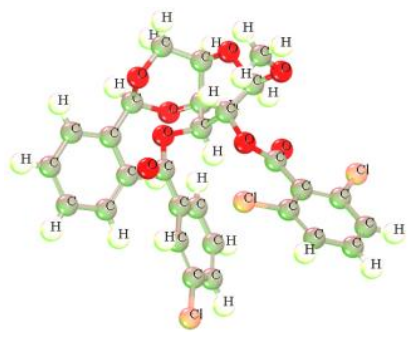

Methyl 4,6-O-benzylidene2-O-(2,6-dichlorobenzoyl)3-O-(3-chlorobenzoyl)- $\alpha-\mathrm{D}-$ glucopyranoside (10)

Figure 1. Optimised structure of the derivatives 
Table 1. Frontier molecular orbitals and reactivity descriptor analysis

\begin{tabular}{|c|c|c|c|c|c|c|c|c|c|c|}
\hline Entry & $\begin{array}{c}\text { ELUMO, } \\
\mathrm{eV}\end{array}$ & $\begin{array}{c}\text { EHOMO, } \\
\text { eV }\end{array}$ & $\begin{array}{l}\text { EHOMO } \\
\text { ELUMO } \\
\text { gap, eV }\end{array}$ & $\begin{array}{c}\text { Ionisation } \\
\text { potential } \\
\text { (I), eV }\end{array}$ & $\begin{array}{l}\text { Electron } \\
\text { affinity } \\
\text { (A), eV }\end{array}$ & $\begin{array}{c}\text { Chemical } \\
\text { potential } \\
(\mu), \mathrm{eV}\end{array}$ & $\begin{array}{c}\text { Hardness } \\
(\eta), \mathrm{eV}\end{array}$ & $\begin{array}{l}\text { Electrons } \\
\text { activity } \\
(\chi), \mathrm{eV}\end{array}$ & $\begin{array}{c}\text { Electrophilicity } \\
(\omega), \mathrm{eV}\end{array}$ & $\begin{array}{c}\text { Softness } \\
(\mathrm{S}), \mathrm{eV}\end{array}$ \\
\hline 1 & -0.165 & -8.973 & 8.808 & 8.973 & 0.165 & -4.569 & 4.386 & 4.569 & 2.379 & 0.228 \\
\hline 2 & -1.685 & -8.445 & 6.760 & 8.445 & 1.685 & -5.056 & 3.638 & 5.056 & 3.513 & 0.275 \\
\hline 3 & -1.552 & -8.886 & $7 \cdot 334$ & 8.886 & 1.552 & -5.219 & 3.667 & 5.219 & 3.714 & 0.273 \\
\hline 5 & -1.224 & -8.238 & 7.014 & 8.238 & 1.224 & -4.731 & 3.507 & 4.731 & 3.191 & 0.285 \\
\hline 6 & -1.425 & -8.824 & 7.425 & 8.824 & 1.425 & -5.124 & 3.699 & 5.124 & 2.562 & 0.270 \\
\hline 7 & -1.680 & -8.889 & 7.209 & 8.889 & 1.680 & -5.284 & 3.604 & 5.284 & 3.873 & 0.277 \\
\hline 8 & -1.550 & -8.528 & 6.978 & 8.528 & $1.55^{\circ}$ & -5.039 & 3.489 & 5.039 & 3.638 & 0.286 \\
\hline 9 & -1.413 & -8.159 & 6.746 & 8.159 & 1.413 & -4.786 & $3 \cdot 373$ & 4.786 & 3.395 & 0.296 \\
\hline
\end{tabular}

客

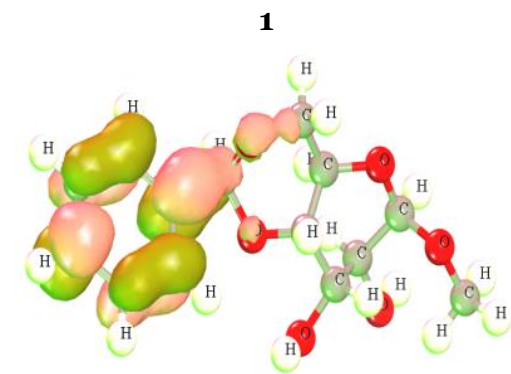

帘

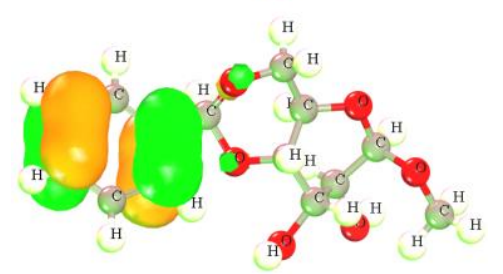

4

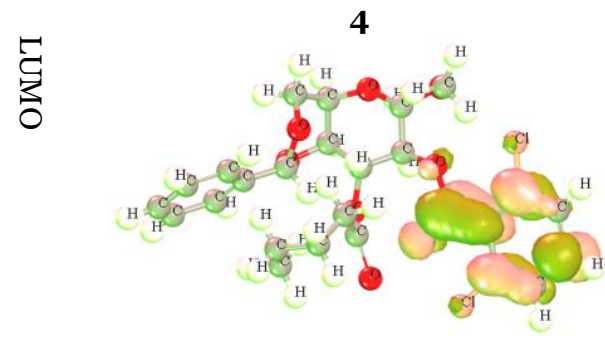

范

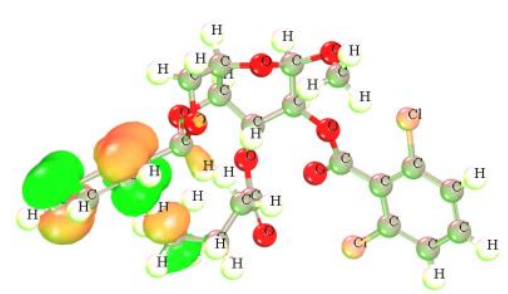

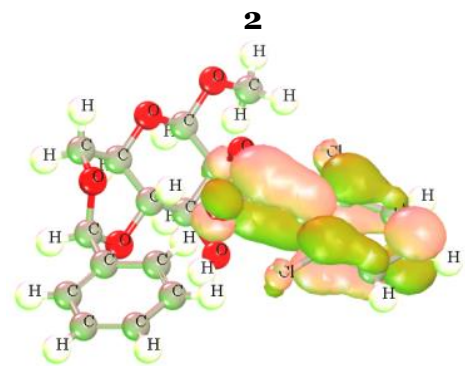

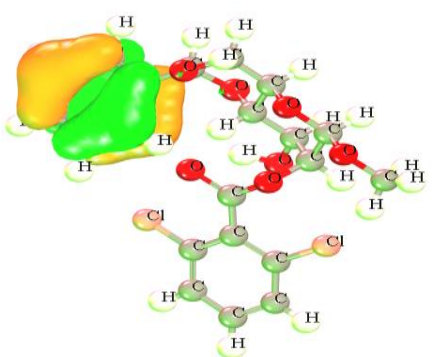

5
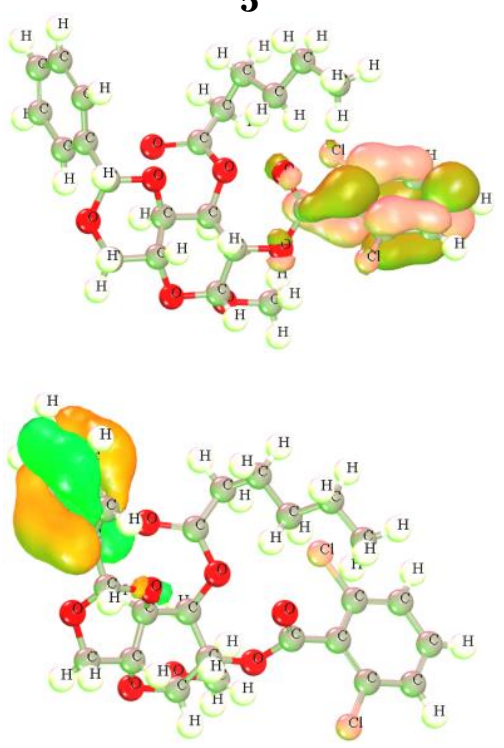

3
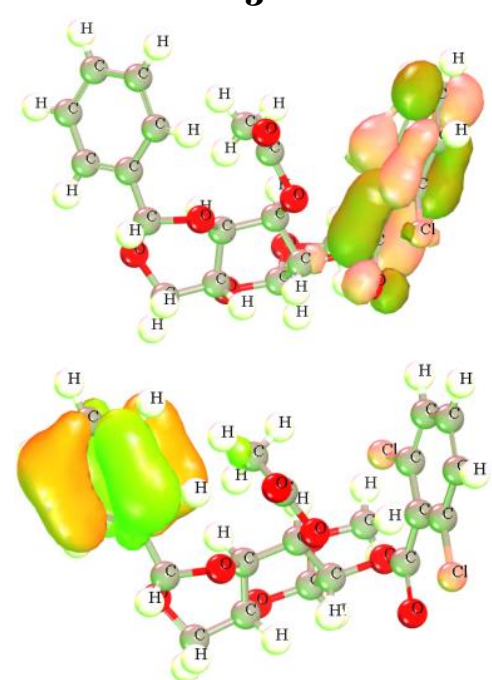

6
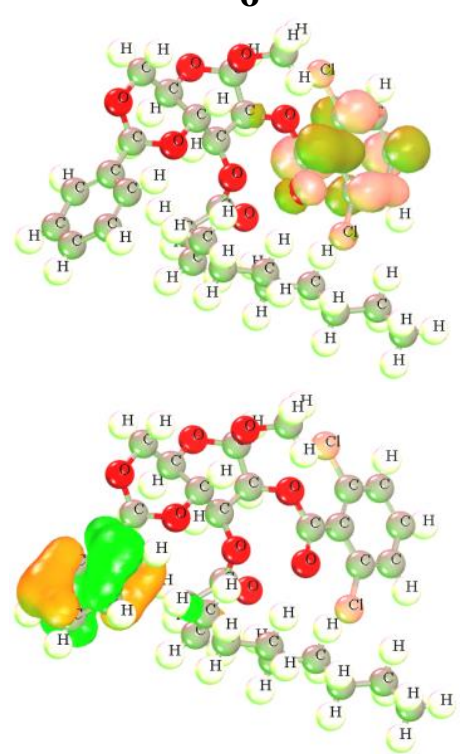

Figure 2. Frontier molecular orbitals diagram for HOMO and LUMO 


\section{Electrostatic Potential (ESP) Charge Distribution}

The ESP map is a valuable factor and way to get the information of distributing charge in molecular surface, positive and negative charge distribution, which leads to identifying a promising site for electrophilic or nucleophilic groups, as well as their hydrophobic and hydrophilic nature (Nath et al., 2020). Figure 3 has been indicated the 3D mapped of electrostatic potential charge distribution whereas the light yellow colour is a negative charge and the green colour is a positive charge. The maximum negative charge involves the inside of an aromatic ring, and the maximum positive charge stays in the outside of the ring whereas the hydrogen atoms have attached with the ring. However, it must be noted that the electrophilic groups might be attached to aromatic ring and the nucleophilic could be rebonded outside the aromatic ring.
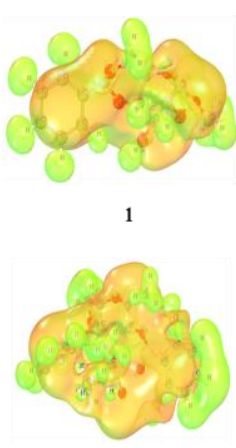

4

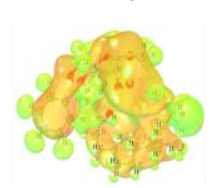

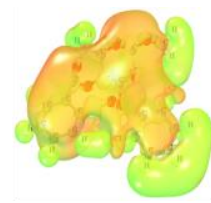

2

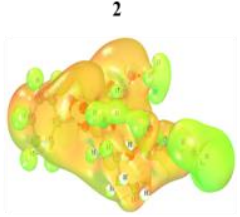

5

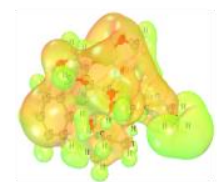

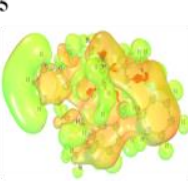

9

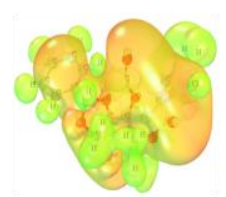

3

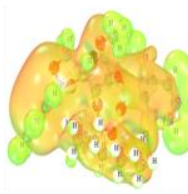

6

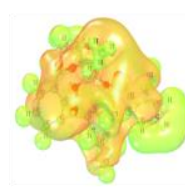

Figure 3. 3D mapped of electrostatic potential charge distribution

\section{Molecular Docking}

Molecular docking studies were conducted to legalise the antimicrobial performance by the evidence of binding affinity for drug derivatives with protein (Hornig et. al., 1987; Babahedari et al., 2013). As the protein-ligand interaction plays a significant role in structural-based drug designing, the $\mathrm{H}$ bonding and hydrophobic bonding are the main cause for docking score where the docking score above $-6.00 \mathrm{kcal} / \mathrm{mol}$ has been considered as standard drug for the docked protein of pathogens (Cheng et. al., 2009; Hermann et. al., 1999; Rana et al., 2021).

From Table 2, it could be revealed that all drug molecules showed good binding energy toward the target protein, Mpro, ranging from -6.20 to $-7.70 \mathrm{kcal} / \mathrm{mol}$ while derivatives $\mathbf{2}, \mathbf{3}$, and $\mathbf{9}$ could be considered as the standard drug with the highest binding affinity although derivatives 4, 8, and 10 has also standard docking score in term of binding energy. In the case of 2 , there is no $\mathrm{H}$-bonding but about 11 hydrophobic bonds are formed which lead the making large binding affinity. However, in derivatives 3 and $\mathbf{9}$, the number of $\mathrm{H}$-bonds is the same but the number of hydrophobic bonds is 4 and 5, respectively. The case of spike protease showed good binding energy toward the target protein ranging from -5.90 to $-7.40 \mathrm{kcal} / \mathrm{mol}$ that is shown in Table 3. The derivatives $\mathbf{2}, \mathbf{3}$, and 9 have obtained the $-7.0,-6.8$, and $-7.1 \mathrm{kcal} / \mathrm{mol}$. It could be suggested from the molecular docking affinity that the derivatives 2, 3, and $\mathbf{9}$ are highly active inhibitors against both Spro and Mpro and the activity of derivatives 2 and 9 have found the towering activity among all drugs, and they have higher value against $\mathrm{M}^{\text {pro }}$ than Spro. There is a small change in $\mathrm{H}$ bonding and hydrophobic bonding between $\mathrm{S}^{\text {pro }}$ and $\mathrm{M}^{\text {pro }}$ that more $\mathrm{H}$ bonding has created for $\mathrm{S}^{\text {pro, }}$, and the various bonding poses of derivative $\mathbf{9}$ are shown in Figure 4; (a to f). Finally, all molecules can show higher inhibition in Spro than Mpro. 


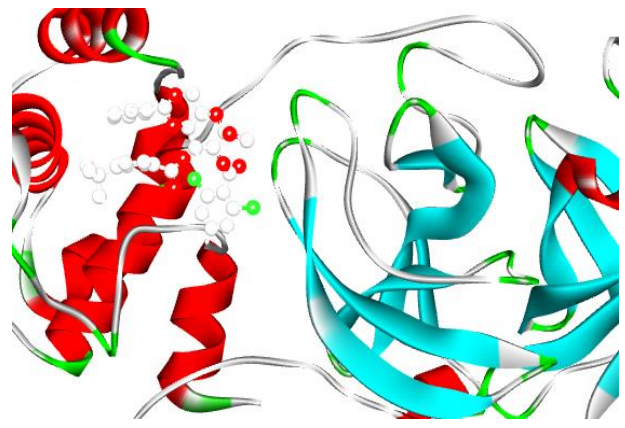

a) Ligand(09) in protein pocket of $M^{\text {pro }}$

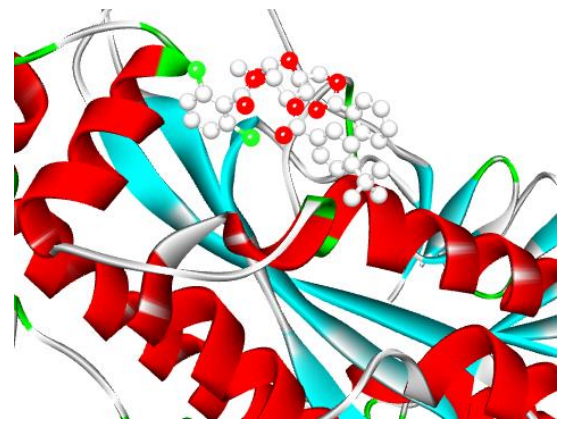

d) Ligand(o9) in protein pocket of Spro

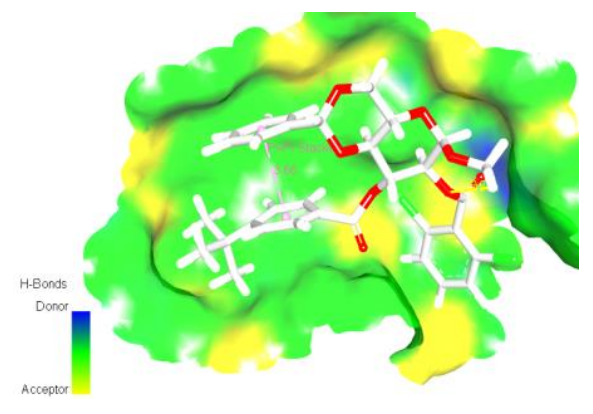

b) H-bonding for Ligand(o9) of Mpro

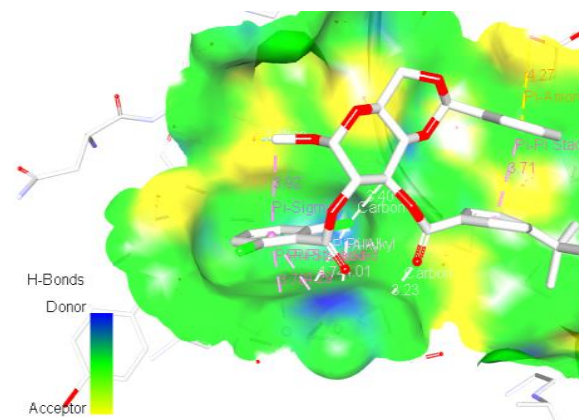

e) H-bonding for Ligand(09) of Spro

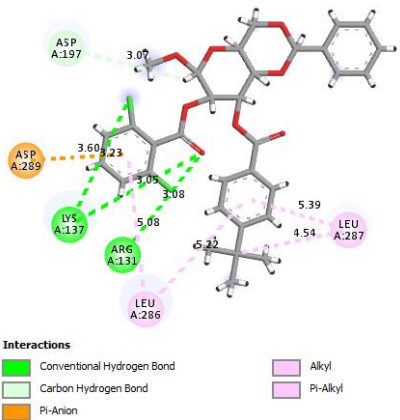

c) $2 \mathrm{D}$ interaction for Ligand(09) of Mpro

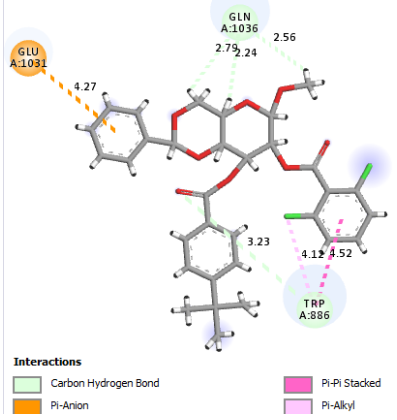

f) $2 \mathrm{D}$ interaction for Ligand(o9) of Spro

Figure 4. Poses of ligand-protein interaction for $\mathrm{M}^{\text {pro }}$ and $\mathrm{S}^{\text {pro }}$ of derivative 09

\section{E. Protein-ligands Interaction}

To design a new drug, the main key factor is ligand-protein interaction that provides the information of binding or bonding mechanism for drugs with the protein of virus or micro pathogens and illustrates the specific amino acid residue of protein where the ligand is to be bonded (Kumar \& Khan 2021). The interaction of the drug molecule with the main protease, $5 \mathrm{r} 7 \mathrm{y}$, of the coronavirus has been investigated with bond distance. From Table 4, it is illustrated that there are two types of bonds, $\mathrm{H}$ - bond and hydrophobic bond but the Van der Waals bond is not presented for all drugs. For derivative 2, no hydrogen bond was formed although its docking score almost near to highest inhibitor is formed with SARS-CoV-2 protein, whereas the hydrogen bonds distance is lower than hydrophobic bond distance. Similarly, the type of bond interaction with bond distance for all drugs is listed in Table 4.

Table 2. Data of binding energy and name of interacted ligand for Main Protease (Mpro)

\begin{tabular}{|c|c|c|c|c|c|}
\hline Entry & $\begin{array}{l}\text { Binding affinity } \\
\text { (kcal/mol) }\end{array}$ & $\begin{array}{l}\text { No. of H- } \\
\text { bond }\end{array}$ & $\begin{array}{c}\text { No. of hydrophobic } \\
\text { bond }\end{array}$ & $\begin{array}{l}\text { No. of van der } \\
\text { Waals bond }\end{array}$ & Total bonds \\
\hline 1 & -6.4 & 05 & 01 & absent & 06 \\
\hline 2 & -7.7 & absent & 11 & absent & 11 \\
\hline 3 & $-7 \cdot 3$ & 03 & 04 & absent & 07 \\
\hline 4 & -6.7 & 02 & 05 & absent & 07 \\
\hline 5 & -6.2 & 03 & $\mathrm{O} 2$ & absent & O5 \\
\hline 6 & -6.4 & O3 & O3 & absent & 06 \\
\hline 7 & -6.5 & 03 & 10 & absent & 13 \\
\hline 8 & -6.6 & O5 & O5 & absent & 10 \\
\hline
\end{tabular}




\begin{tabular}{cccccc}
\hline 9 & & & & & \\
\hline 10 & -7.7 & 03 & 05 & absent & 08 \\
07 & 03 & absent & 03 \\
\hline
\end{tabular}

Table 2. Data of binding energy and name of interacted ligand for spike protease (Spro)

\begin{tabular}{cccccc}
\hline Entry & $\begin{array}{c}\text { Binding affinity } \\
(\mathrm{kcal} / \mathrm{mol})\end{array}$ & No. of H- bond & No. of hydrophobic bond & No. of van der Waals bond & Total bonds \\
\hline 1 & -6.4 & 02 & 03 & absent & 05 \\
2 & -7.0 & 01 & 04 & absent & 05 \\
3 & -6.8 & 05 & 04 & absent & 09 \\
4 & -6.4 & 02 & 05 & absent & 07 \\
5 & -5.9 & 03 & 03 & absent & 06 \\
6 & -6.0 & 01 & 06 & absent & 07 \\
7 & -6.6 & 01 & 05 & absent & 06 \\
8 & -7.4 & 04 & 08 & absent & 12 \\
9 & -7.1 & 02 & 05 & absent & 07 \\
10 & -7.1 & 03 & 09 & absent & 12 \\
\hline
\end{tabular}

Table 3. Main protease of SARS-CoV-2 and Ligands Interaction with amino acid residues and their bond distance

\begin{tabular}{|c|c|c|c|c|}
\hline \multirow[t]{2}{*}{ Entry } & \multicolumn{2}{|c|}{ Hydrogen bond } & \multicolumn{2}{|c|}{ Hydrophobic bond } \\
\hline & Interacting residue of amino acid & Distance, $\mathrm{A}^{\circ}$ & $\begin{array}{c}\text { Interacting residue of } \\
\text { amino acid }\end{array}$ & Distance, $\mathrm{A}^{\circ}$ \\
\hline \multirow[t]{4}{*}{1} & TYR-237 & 1.89 & LEU-286 & 4.67 \\
\hline & THR-199 & 3.18 & & \\
\hline & THR-199 & 3.01 & & \\
\hline & LEU-287 & 3.26 & & \\
\hline \multirow[t]{11}{*}{2} & absent & & PRO-293 & $5 \cdot 38$ \\
\hline & & & PRO-132 & 4.70 \\
\hline & & & PRO-108 & 4.08 \\
\hline & & & PRO-108 & 4.09 \\
\hline & & & ILE-249 & 3.56 \\
\hline & & & ILE-200 & 3.25 \\
\hline & & & ILE-200 & 5.07 \\
\hline & & & VAL-202 & 5.16 \\
\hline & & & VAL-202 & 4.52 \\
\hline & & & HIS-246 & 3.85 \\
\hline & & & GLU-240 & 3.49 \\
\hline \multirow[t]{4}{*}{3} & ARG-298 & 2.96 & ARG-298 & 3.70 \\
\hline & THR-292 & $3 \cdot 30$ & VAL-303 & 5.13 \\
\hline & GLN-110 & 2.94 & VAL-104 & 4.10 \\
\hline & & & VAL-104 & 4.72 \\
\hline \multirow[t]{2}{*}{4} & THR-199 & 3.11 & LYS-137 & 4.50 \\
\hline & THR-199 & 3.07 & LEU-286 & 5.48 \\
\hline
\end{tabular}




\begin{tabular}{|c|c|c|c|c|}
\hline & & & LEU-286 & $5 \cdot 32$ \\
\hline & & & LEU-287 & 4.34 \\
\hline & & & MET-276 & 4.74 \\
\hline \multirow[t]{3}{*}{5} & THR-199 & 3.07 & LEU-287 & 3.82 \\
\hline & THR-199 & 3.48 & LEU-286 & 5.14 \\
\hline & TYR-239 & 3.49 & & \\
\hline \multirow[t]{3}{*}{6} & TYR-239 & 3.25 & TYR-237 & 4.78 \\
\hline & THR-199 & 2.86 & LEU-286 & 4.84 \\
\hline & LYS-137 & 3.28 & LYS-137 & 4.86 \\
\hline \multirow[t]{10}{*}{7} & GLU-166 & 3.03 & PRO-168 & 4.24 \\
\hline & GLU-166 & 3.44 & LEU-167 & 5.41 \\
\hline & PHE-140 & 3.63 & LEU-27 & 4.12 \\
\hline & & & MET-165 & 4.01 \\
\hline & & & MET-49 & 5.70 \\
\hline & & & HIS-41 & 4.63 \\
\hline & & & HIS-41 & 4.66 \\
\hline & & & CYS-145 & 4.42 \\
\hline & & & CYS-145 & $5 \cdot 33$ \\
\hline & & & CYS-145 & 4.21 \\
\hline \multirow[t]{5}{*}{8} & THR-199 & 3.22 & LYS-137 & 4.62 \\
\hline & THR-199 & 3.28 & LEU-286 & 4.06 \\
\hline & THR-199 & 2.71 & LEU-286 & 3.73 \\
\hline & ASN-238 & $3 \cdot 51$ & LEU-286 & 5.14 \\
\hline & LYS-137 & 3.11 & LEU-287 & 4.73 \\
\hline \multirow[t]{5}{*}{9} & LYS-137 & 3.05 & LEU-287 & $5 \cdot 39$ \\
\hline & LYS-137 & 3.23 & LEU-287 & 4.54 \\
\hline & ARG-131 & 3.08 & LEU-286 & 5.22 \\
\hline & & & LEU-286 & 5.08 \\
\hline & & & ASP-289 & 3.60 \\
\hline \multirow[t]{4}{*}{10} & TYR-37 & 3.14 & TYR-101 & 3.14 \\
\hline & TYR-37 & 2.80 & PHE-103 & 4.23 \\
\hline & TYR-101 & 3.89 & LYS-88 & 3.94 \\
\hline & TYR-101 & 3.04 & & \\
\hline
\end{tabular}

In the view of Spro, the $\mathrm{H}$ bonding interaction and hydrophobic bonds are illustrated in Table 5. Overall, the $\mathrm{H}$ bonds have more interacted strongly with protein because its bond distance is less than the hydrophobic bond and Van der Waals bonds in all cases. For derivative 2, one H-bond and three hydrophobic bonds are formed with SARS-CoV-2 protein, whereas the hydrogen bond distance is lower than the hydrophobic bond distance. From the protein-drug interaction, it could be difficult to say about the effect of specific bonds on docking score that which bond is directly involved in forming the higher molecular docking score but it has been observed that the bond distance of $\mathrm{H}$ bonding is less than the hydrophobic bond, as well as lower H-bond number. 
Table 4. Spike Protein of SARS-CoV-2 and ligands interaction with amino acid residues and their bond distance

\begin{tabular}{|c|c|c|c|c|}
\hline \multirow[t]{2}{*}{ Entry } & \multicolumn{2}{|c|}{ Hydrogen bond } & \multicolumn{2}{|c|}{ Hydrophobic bond } \\
\hline & $\begin{array}{c}\text { Interacting residue of } \\
\text { amino acid }\end{array}$ & Distance, $\mathrm{A}^{\circ}$ & $\begin{array}{c}\text { Interacting residue of } \\
\text { amino acid }\end{array}$ & Distance, $\mathrm{A}^{\circ}$ \\
\hline \multirow[t]{3}{*}{1} & TYR-170 & 2.33 & ILE-203 & 3.71 \\
\hline & SER-172 & 2.36 & ILE-119 & 5.09 \\
\hline & & & TRP-104 & $5 \cdot 56$ \\
\hline \multirow[t]{3}{*}{2} & GLN-1036 & 3.14 & TRP-886 & 4.49 \\
\hline & & & ARG-905 & 5.27 \\
\hline & & & LEU-1034 & 5.24 \\
\hline \multirow[t]{5}{*}{3} & SER-172 & 2.97 & ILE-203 & 3.80 \\
\hline & SER-205 & 3.56 & ILE-119 & 5.09 \\
\hline & TYR-170 & 2.89 & VAL-227 & 5.45 \\
\hline & HIS-207 & 3.56 & LEU-226 & 4.11 \\
\hline & HIS-207 & $3 \cdot 77$ & & \\
\hline \multirow[t]{5}{*}{4} & SER-205 & 3.25 & ILE-203 & 3.65 \\
\hline & HIS-207 & 3.65 & ILE-119 & 4.96 \\
\hline & & & ILE-119 & 5.42 \\
\hline & & & TRP-104 & 5.84 \\
\hline & & & TRP-104 & 5.00 \\
\hline \multirow[t]{3}{*}{5} & THR-602 & 2.98 & PHE-58 & 4.96 \\
\hline & LYS-300 & 3.09 & PHE-59 & 5.03 \\
\hline & SER-297 & 3.40 & VAL-289 & 4.85 \\
\hline \multirow[t]{6}{*}{6} & THR-883 & 2.84 & PRO-792 & 5.44 \\
\hline & & & ILE-794 & 5.21 \\
\hline & & & PHE-797 & 4.95 \\
\hline & & & ALA-893 & 3.80 \\
\hline & & & ALA-893 & 4.92 \\
\hline & & & TYR-789 & 4.78 \\
\hline \multirow[t]{4}{*}{7} & GLN-1036 & 3.12 & TRP-886 & $4 \cdot 33$ \\
\hline & & & TRP-886 & 4.80 \\
\hline & & & TYR-904 & $4 \cdot 30$ \\
\hline & & & LEU-1034 & 5.15 \\
\hline \multirow[t]{8}{*}{8} & ARG-190 & 3.29 & VAL-126 & 5.12 \\
\hline & ASN-121 & 3.10 & VAL-126 & 5.44 \\
\hline & HIS-207 & 3.11 & VAL-127 & $5 \cdot 50$ \\
\hline & ALA-123 & 3.79 & VAL-127 & 5.25 \\
\hline & & & ILE-119 & 4.79 \\
\hline & & & ILE-203 & $5 \cdot 38$ \\
\hline & & & LEU-226 & 3.72 \\
\hline & & & LEU-226 & 4.39 \\
\hline \multirow[t]{3}{*}{9} & GLN-1036 & 3.63 & TRP-886 & 4.12 \\
\hline & TRP-886 & 3.23 & TRP-886 & 4.52 \\
\hline & & & GLU-4.27 & 4.27 \\
\hline \multirow[t]{2}{*}{10} & ASN-121 & 3.20 & HIS-207 & 5.10 \\
\hline & ASN-121 & 3.63 & VAL-126 & 5.47 \\
\hline
\end{tabular}




$\begin{array}{lcc}\text { HIS-207 } & \text { VAL-126 } & 4.79 \\ & \text { VAL-227 } & 3.59 \\ & \text { LEU-226 } & 5.25 \\ & \text { ILE-203 } & 4.83 \\ & \text { ILE-119 } & 4.17 \\ & \text { TRP-104 } & 4.92 \\ & \text { PHE-192 } & 5.34\end{array}$

[Note: ALA = Alanine, ARG = Arginine, ASN = Asparagine, ASP = Aspartic acid, CYS = Cysteine, GLU = Glutamic acid, GLN $=$ Glutamine, GLY = Glycine, HIS = Histidine, ILE = Isoleucine, LYS = Lysine, LEU = Leucine, MET = Methionine, $\mathrm{PRO}=$ Proline, $\mathrm{PHE}=$ Phenylalanine, $\mathrm{TRP}=$ Tryptophan, $\mathrm{THR}=$ Threonine, $\mathrm{VAL}=$ Valine, $\mathrm{SER}=\mathrm{Serine}, \mathrm{TRP}=\mathrm{Tryptophan}]$

\section{F. Pharmacokinetics and Drug-likeness Study}

According to Christopher A. Lipinski's rule for drug molecules, it has less the 5 hydrogen bond donors and less than 10 hydrogen bond acceptors, whereas the number of rotatable bonds are three or more, but the molecular mass is less than 500 Daltons (Lipinski et al., 2001). The fifth view is the octanol-water partition coefficient expressed as log $\mathrm{P}_{\mathrm{o} / \mathrm{w}}$ and it is not greater than 5 . Using the Swiss Institute of Bioinformatics online database was used to evaluate the pharmacokinetics and drug-likeness applying the Lipinski rule from link https://www.sib.swiss/, and make a comparison study as drug activity (Daina et. al., 2017; Guex et al., 1997). Table 6 demonstrated that derivatives 1 to 5 follow the Lipinski rule as a drug but derivatives 6-9 do not convey this rule.

\section{G. Pharmacokinetics and ADMET Studies}

The full abbreviation of ADMET is the absorption, distribution, metabolism, excretion, and toxicity which are deemed to be the fundamental parts of any drug development program (Nath et al., 2021). To minimise the cost and time, the prediction of ADME data helps design a new drug design. Such events created a severe disruption of the development process and often resulted in the closure of the project and a lost opportunity. As a result, the situation of drug discovery has been rapidly and dramatically changing (Kumar \& Khan, 2021). ADME and toxicology technologies have evolved to permit the use of rapid and less expensive methods that have made the early assessment of drug candidates very much attractive to the pharmaceutical industry. The absorption, distribution, metabolism, and excretion parameters have listed in Table 7 . For the bloodbrain Barrier, all show positive activity except derivative 1, and it is similar for Human Intestinal Absorption and Caco2 Permeability. Moreover, they showed a positive result for P-II glycoprotein substrate and the opposite for CYP45O 2C9 substrate and CYP45O 1A2 Inhibitor. Finally, the Mitochondria are the sub-cellular localisation for all tested molecules.

Table 5. Data of Lipinski rule, pharmacokinetics, and drug-likeness

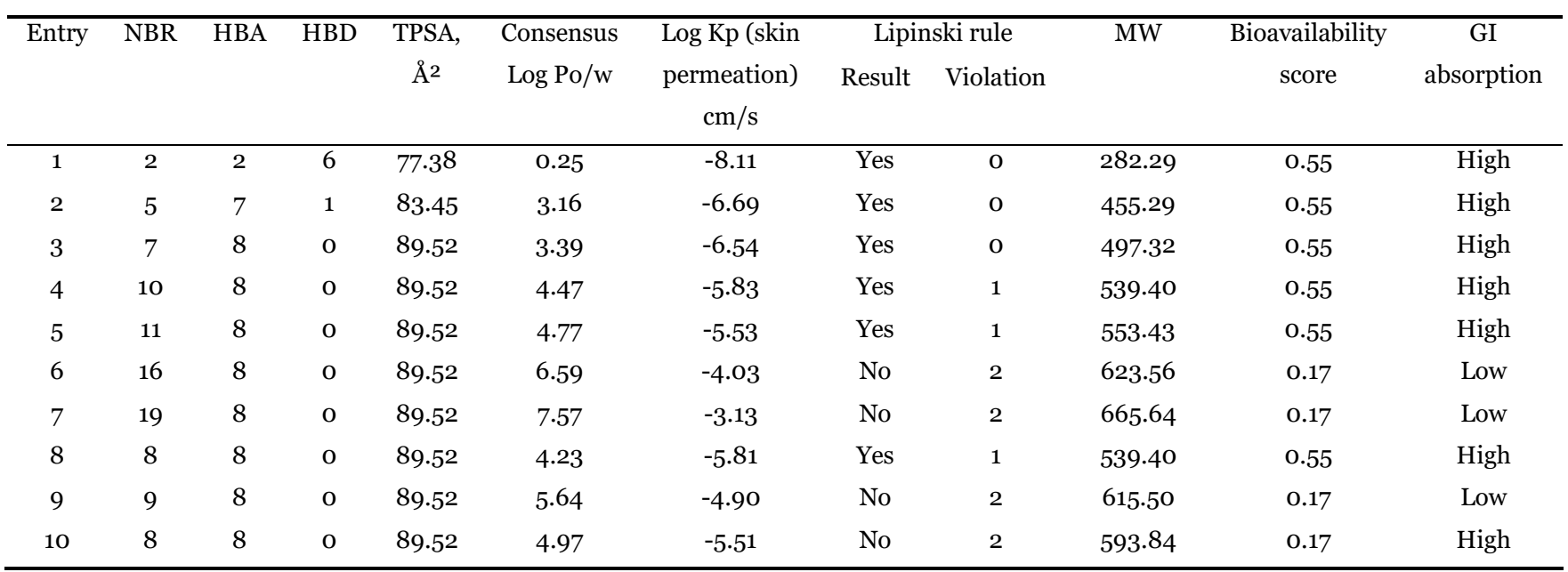


Table 6. Data for ADME parameters

\begin{tabular}{|c|c|c|c|c|c|c|c|c|c|}
\hline Entry & $\begin{array}{c}\text { Human } \\
\text { intestinal } \\
\text { absorption }\end{array}$ & $\begin{array}{c}\text { Caco-2 } \\
\text { permeability }\end{array}$ & $\begin{array}{l}\text { Blood } \\
\text { brain } \\
\text { barrier }\end{array}$ & $\begin{array}{c}\text { P-I } \\
\text { glycoprotein } \\
\text { inhibitor }\end{array}$ & $\begin{array}{c}\text { P- II } \\
\text { glycoprotein } \\
\text { substrate }\end{array}$ & $\begin{array}{c}\text { Renal } \\
\text { organic } \\
\text { cation } \\
\text { transporter }\end{array}$ & $\begin{array}{l}\text { Sub-cellular } \\
\text { localisation }\end{array}$ & $\begin{array}{c}\text { CYP45O } \\
\text { 2C9 } \\
\text { substrate }\end{array}$ & $\begin{array}{c}\text { CYP45O } \\
\text { 1A2 } \\
\text { inhibitor }\end{array}$ \\
\hline 1 & -0.7865 & +0.5598 & No & No & Yes & 0.8667 & Mitochondria & No & No \\
\hline 2 & 0.7548 & -0.5501 & Yes & No & Yes & 0.8469 & Mitochondria & No & No \\
\hline 3 & 0.8887 & -0.5710 & Yes & No & No & 0.8775 & Mitochondria & No & No \\
\hline 4 & 0.8812 & - 0.6708 & Yes & Yes & Yes & 0.8410 & Mitochondria & No & No \\
\hline 5 & 0.8812 & -0.6660 & Yes & Yes & Yes & 0.8379 & Mitochondria & No & No \\
\hline 6 & 0.8812 & -0.7587 & Yes & Yes & Yes & 0.8166 & Mitochondria & No & No \\
\hline 7 & 0.8812 & -0.7898 & Yes & Yes & Yes & 0.8166 & Mitochondria & No & No \\
\hline 8 & 0.8902 & -0.6615 & Yes & Yes & Yes & 0.8998 & Mitochondria & No & No \\
\hline 9 & 0.8902 & -0.7462 & Yes & Yes & Yes & 0.8998 & Mitochondria & No & No \\
\hline 10 & 0.8738 & -0.6661 & Yes & Yes & No & 0.8637 & Mitochondria & No & No \\
\hline
\end{tabular}

\section{H. Aquatic and Non-aquatic Toxicity}

Table 8 displayed the toxicity of required drugs in the case of acute and non-acute species, testing on rats and fish, which were obtained by an online database for computational prediction. It was observed that all drugs have more solubility in water medium. As a result, most drugs are toxic for fish where the pLC50 score is about 1.2510 to -0.2105 $\mathrm{mg} / \mathrm{L}$ as non-aquatic species, rat. Finally, all drugs are noncarcinogenic, as well as no responsibility for AMES toxicity.

Table 7. Aquatic and non-aquatic toxicity

\begin{tabular}{|c|c|c|c|c|c|c|c|c|}
\hline Entry & $\begin{array}{l}\text { AMES } \\
\text { toxicity }\end{array}$ & Carcinogenicity & $\begin{array}{c}\text { Water } \\
\text { solubility, } \\
\text { Log S }\end{array}$ & $\begin{array}{l}\text { Plasma } \\
\text { protein } \\
\text { binding }\end{array}$ & $\begin{array}{c}\text { Acute } \\
\text { oral } \\
\text { toxicity, } \\
\mathrm{kg} / \mathrm{mol}\end{array}$ & $\begin{array}{l}\text { Oral rat } \\
\text { acute } \\
\text { toxicity } \\
(\mathrm{LD} 50) \\
(\mathrm{mol} / \mathrm{kg})\end{array}$ & $\begin{array}{c}\text { Fish } \\
\text { toxicity } \\
\text { pLC50 } \\
\text { mg/L }\end{array}$ & $\begin{array}{c}\mathrm{T} . \\
\text { pyriformis toxicity } \\
(\log \mathrm{ug} / \mathrm{L})\end{array}$ \\
\hline 1 & No & No & -2.969 & 1.078 & 2.071 & 2.2267 & 1.2510 & 0.749 \\
\hline 2 & No & No & -4.372 & 1.304 & 2.754 & 3.5962 & 0.3078 & 1.321 \\
\hline 3 & No & No & -4.446 & 1.181 & 2.622 & 2.8439 & -0.192 & 1.475 \\
\hline 4 & No & No & -5.026 & 1.24 & 3.17 & 2.8195 & -0.079 & 1.558 \\
\hline 5 & No & No & -5.218 & 1.228 & 3.105 & 2.8373 & 0.1516 & 1.708 \\
\hline 6 & No & No & $-5 \cdot 38$ & 1.212 & 2.999 & 2.8930 & 0.1269 & 2.686 \\
\hline 7 & No & No & $-5 \cdot 38$ & 1.22 & 2.979 & 2.8930 & 0.1269 & 2.697 \\
\hline 8 & No & No & -4.681 & 1.19 & 2.55 & 2.6472 & -0.210 & 1.552 \\
\hline 9 & No & No & -4.681 & 1.312 & 2.457 & 2.6472 & -0.210 & 1.814 \\
\hline 10 & No & No & -4.489 & 1.255 & 2.319 & 2.8059 & -0.145 & 1.713 \\
\hline
\end{tabular}

\section{Molecular Dynamics}

The molecular dynamics is a boulevard for trying the fluctuation (RMSF) which provide in rank about their accuracy docking procedure in the prospect of the root- binding pose ligand-protein complex after docking (Trott et mean-square deviation (RMSD) and root-mean-square al., 2010). It is divulged that the RMSD of the docking 
complex is less than $2 \AA$ for becoming a good fitting pose of first three figures. The RMSD has obtained less than 2.0 $\AA$ ligand in drug pocket and software can accurately dock the within time 2000 ps but it has increased $2.5 \AA$ at 5000 ps ligand-protein complex (Bertamino et. al., 2018; Talarico et time for no bond or interaction. But the RMSD has changed al., 2020). Then it makes parallel both docked pose with that of the docked complex by RMSD; a lower value indicates the accuracy and highly stable ligand-protein complex in the docking method (Liu et. al., 2017; Guterres et $a l ., 2020)$. The stability of these three docked complexes was evaluated using protein-ligand RMSD, ligand-protein interaction and hydrogen bonding, and ligand RMSF among others. In this study, the RMSD was calculated for time (o$5000 \mathrm{~ns}$ ) and interaction of amino acid residues of the protein. Firstly, it is noted that the RMSD illustrates in (Figure 5; a to $\mathrm{f}$ ) in terms of time and amino acid residue dependent where an innovative relationship is found for the after the formation of backbone or hydrogen bond. The RMSD has decreased from 2.5 $\AA$ to below $1.0 \AA$ in terms of backbone interaction after docking, indicating high accuracy and stability of docked complexes, but the hydrogen bonding showed a little reduction of RMDS value from on bond. It could be concluded that hydrogen bonds are little response for molecular docking affinity and stability of the docked complex, showing RMSD is at about 2.5 $\AA$, but the hydrophobic bonds in the interaction of protein-ligand lead the major role for docking score and stability while the docked complexes show the value less than 1.0 $\AA$ even derivative 02 has less than $0.7 \AA$.

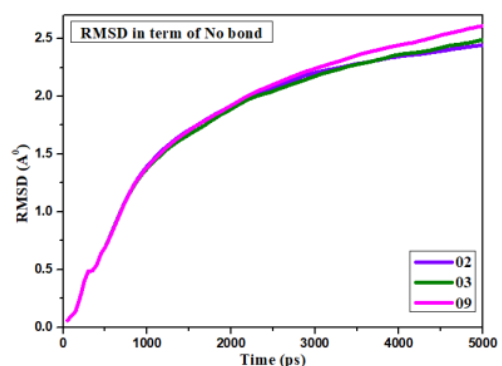

a) RMSD: Time vs number of bond

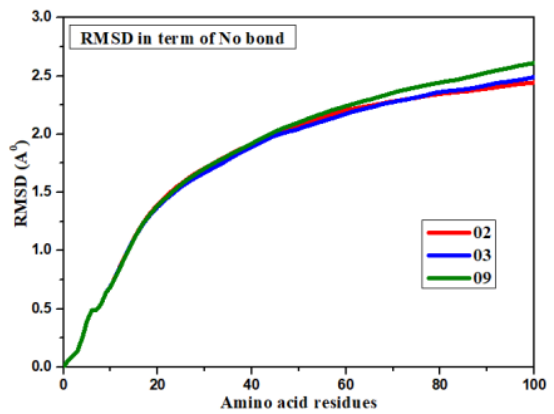

d) RMSD: Amino acid vs. no bond

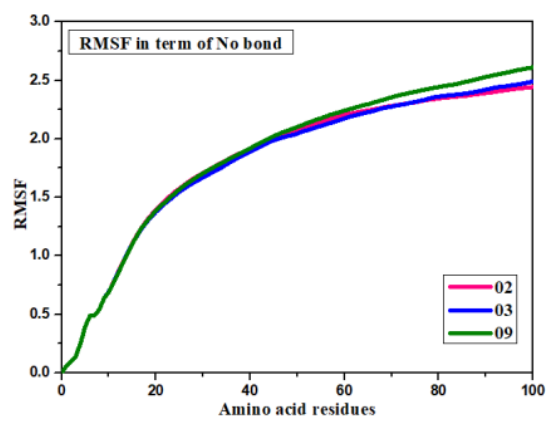

g) RMSF: Amino acid vs. no bond

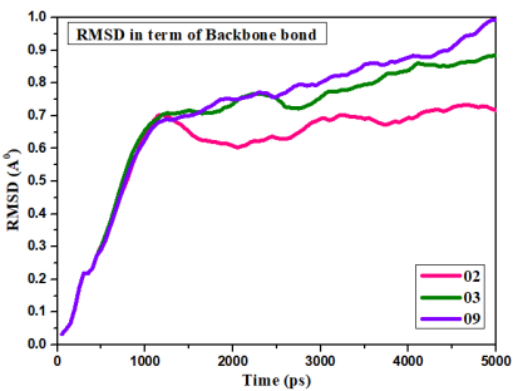

b) RMSD: Time vs. protein skeleton

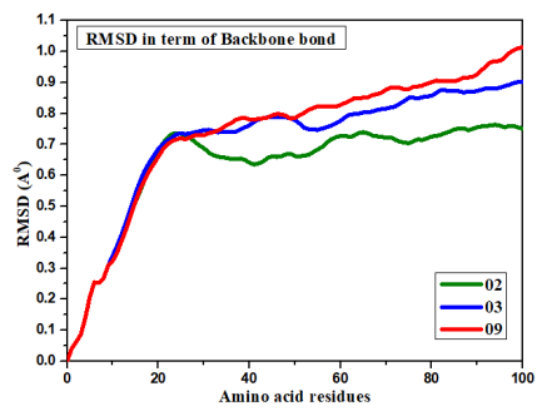

e) RMSD: Amino acid vs. backbond

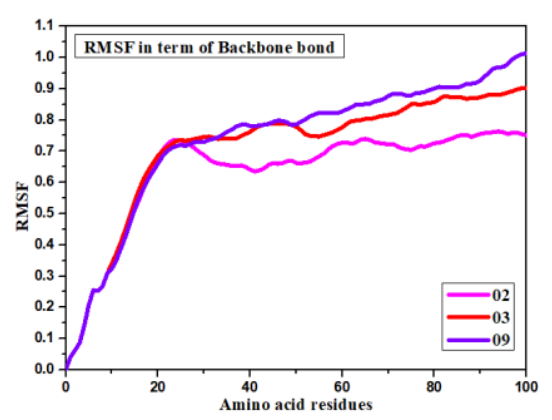

h) RMSF: Amino acid vs. backbond

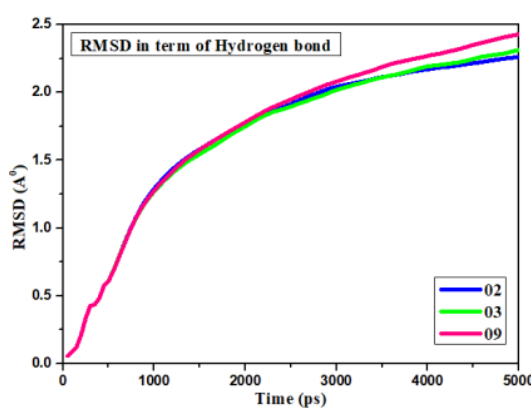

c) RMSD: Time vs. Hydrogen bond

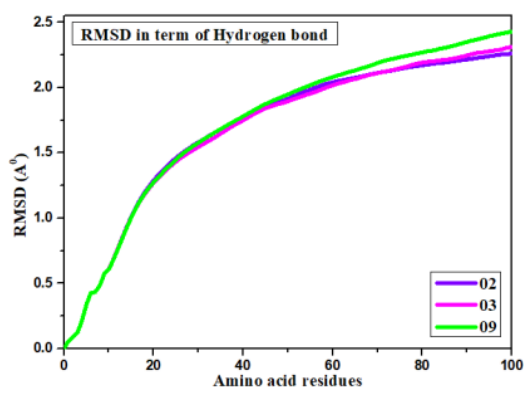

f) RMSD: Amino acid vs. H bond

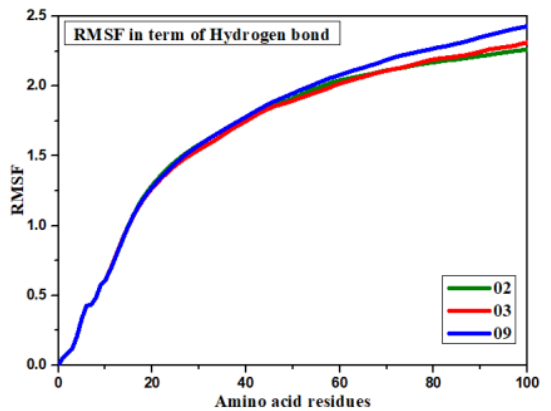

i) RMSF: Amino acid vs. $\mathrm{H}$ bond

Figure 5. RMSD and RMSF curves of protein-ligand interaction of docked complexes (02, 03, and o9) for Mpro 


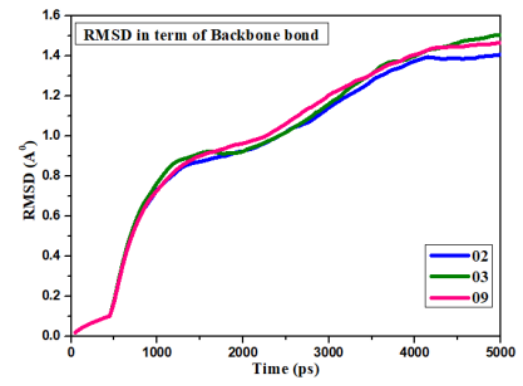

a)RMSD: Time vs. protein skeleton

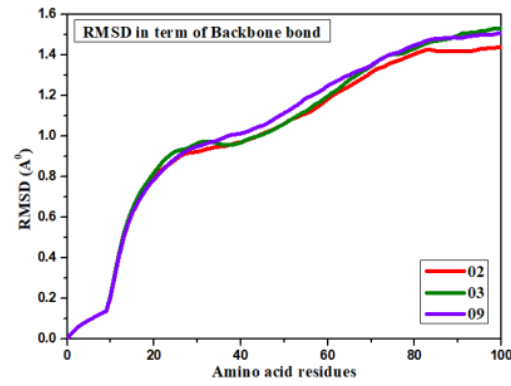

b) RMSD: Amino acid vs. backbond

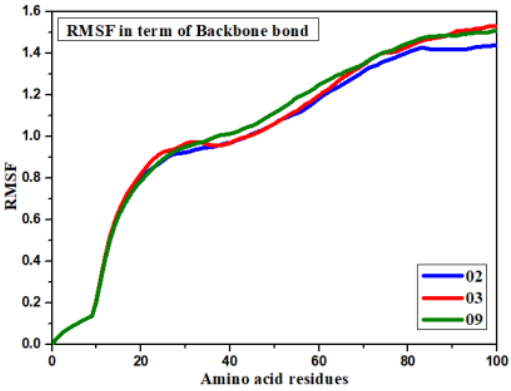

c) RMSF: Amino acid vs. backbond

Figure 6. RMSD and RMSF curves of protein-ligand interaction of docked complexes (02, 03, and o9) for Spro

In view of the RMSF of the docked complexes, the lower value of RMSF mentions their higher stability. From (Figure 5; $\mathrm{g}, \mathrm{h}$, and i), it has been found that the RMSF lays about $2.5 \AA$ when it has no bonding or interaction as ligandprotein interaction. Regarding the hydrogen bond, it puts down 2.2 $\AA$ which means that the hydrogen bond is little response for stability. But it has shifted down 1.0 $\AA$ due to backbone interaction while derivatives 2,3 , and 9 showed the minimum RMSF is about $0.7 \AA$, meaning the highest stability of the docked complexes.

In the case of Spro, the MD was performed based on RMSD and RMSF for the protease and ligand complex after docking. The RMSD value is about $3.0 \AA$ which has occurred without any bond between protein and ligand interaction. It has decreased by about $1.4 \AA$, which is indicated as the standard drug. When H-bond is created, the RMSD is about $2.9 \AA$ while the RMSF was about $3.0 \AA$ which is not a good result for standard drugs. But, when bonds were created as backbone bonds with protein residue, the RMSD was in 1.6 to 1.0 $\AA$, and RMSF was about 1.6 to $1.2 \AA$ for the first six drugs. On the other hand, H-bonds, both RMSD and RMSF were in about 3.0 ̊ shown in (Figure 6; a, b, and c).

\section{CONCLUSION}

The ten natural bioactive D-glucopyranoside derivatives have been examined for computational investigation against both Mpro and Spro. The HOMO LUMO energy gap of Dglucopyranoside derivatives has been found about -4.569 to $-5.284 \mathrm{kcal} / \mathrm{mole}$, and softness is about 0.228 to 0.296 , which supports the highest dissociation as drugs entering the human body. Among them, derivative 9 showed the highest softness value as well as the highest value of hardness. Regarding the data of molecular docking in terms of binding affinity, it suggested that all drugs exhibited an excellent binding affinity with both Mpro and Spro for SARS$\mathrm{CoV}$-2. However, derivatives 2, 3, 4, 8, 9, and 10 showed the docking score as binding energy at -7.7, -7.3, -6.7, -6.6, $7 \cdot 7$, and $-6.7 \mathrm{kcal} / \mathrm{mol}$ for $\mathrm{M}^{\text {pro }}$ whereas the binding affinity for Spro is at -7.0, -6.8, -6.4, -7.1, -7.1 and -7.1 kcal/mol, and it has to be noted that above $-6.0 \mathrm{kcal} / \mathrm{mol}$ binding energy can be considered as an efficient standard drug against any micro-pathogens. Therefore, it could be resolved on the basis of binding affinity that the ten natural bioactive $\mathrm{D}$ glucopyranoside and its derivatives are highly efficient inhibitors for both $M^{\text {pro }}$ and Spro. The RMSD and RMSF were about 2.6 $\AA$ when the ligand-protein interaction had not occurred bonding between ligand and protein, but it had been shifted in the value below $0.9 \AA$ for both RMSD and RMSF; it must be revealed that the docked complexes stay in the highest stable state entering water system and accurate for docking procedure. For evaluating the mechanism by molecular dynamic, the $\mathrm{H}$-bonding contribution is very poor in docking score in terms of RMSD and RMSF, because its values were about $2.3 \AA$ from $2.6 \AA$. But the RMSD and RMSF were about 0.9 to $0.7 \AA$ for backbone interaction and it stands as the greater contributor for gaining stability of ligand-protein complex for $\mathrm{M}^{\text {pro }}$. But in the case of Spro, the RMSD and RMSF have been found about $1.6 \AA$ for backbone interaction on the ligand-protein complex. Thus, it is revealed that these derivatives are mostly preferred as inhibitors against Mpro than Spro SARS-CoV-2. The pharmacokinetic study showed that they have different values, but 1-5 and 8 drugs were satisfied with the Lipinski rule and others $(\mathbf{0 6}, \mathbf{0 7}, \mathbf{0 9}, \mathbf{1 0})$ were not obeyed. Finally, the ADMET data expressed the essential information as a drug and its application in a human cell with comparative 
low toxicity even all of the drugs were non-carcinogenic materials.

\section{ACKNOWLEDGEMENT}

The authors are honestly thankful to the Ministry of Science and Technology (MOST), Government of the People's
Republic of Bangladesh for providing financial support (Ref.: 39.00.0000.009.06.009.20-1331/Phy's-530) to carry out this research.

\section{REFERENCES}

Abel, T, Jaimelee, I, Engel, R, Filshtinskaya, M, Melkonian, A \& Melkonian, K 2002, 'Preparation and investigation of antibacterial carbohydrate-based surfaces', Carbohydrate Research, vol. 337, pp. 2495-2499.

Ajoy, K, Sunanda, P, Nuruzzaman, SM \& Jahidul, MI 2021, 'The prediction of thermo physical, vibrational spectroscopy, chemical reactivity, biological properties of morpholinium borate, phosphate, chloride and bromide Ionic Liquid: A DFT Study', International Journal of New Chemistry, vol. 6, pp. 236-253.

Ajoy, K, Nuruzzaman, SM \& Sunanda, P 2019, 'The thermo physical, HOMO, LUMO, vibrational spectroscopy and QSAR study of morphonium formate and acetate ionic liquid salts using computational method', Turkish Computational and Theoretical Chemistry, vol. 3, pp. 5968.

Alam, A, Hosen, MA, Hosen, A, Fujii, Y, Ozeki, Y \& Kawsar, SMA2021, 'Synthesis, characterization, and molecular docking against a receptor protein FimH of Escherichia coli (4XO8) of thymidine derivatives', Journal of Mexican Chemical Society, vol. 65, no. 2, pp. 256-276.

AlFindee, MN, Qian, Z, Subedi, YP, Shrestha, JP, Kawasaki, Y, Grilley, M, Takemoto, JT \& Chang, CT 2018, 'One-step synthesis of carbohydrate esters as antibacterial and antifungal agents', Bioorganic \& Medicinal Chemistry, vol. 26, pp. 765-774.

Babahedari, AK, Heidari, EH, Shamsabadi, MK \& Kabiri, H 2013, 'The comprehensive evaluation docking of methicillin drug containing isoxazole derivatives, as targeted antibiotics to Staphylococcus aureus', Journal of Bionanoscience, vol. 7, pp. 288-291.

Bertamino, A, Nunzio, I \& Ostacolo, C 2018, 'Soldovieri, Identification of a potent tryptophan-based TRPM8 antagonist with in vivo analgesic activity', Journal of Medicinal Chemistry, vol. 61, pp. 6140-6152.
Bulbul, MZH, Hosen, MA, Ferdous, J, Chowdhury, TS, Misbah, MMH \& Kawsar, SMA 2021, 'Thermochemical, DFT study, physicochemical, molecular docking and ADMET predictions of some modified uridine derivatives', International Journal of New Chemistry, vol. 8, no. 1, pp. 88-110.

Cheng, F, Li, W, Zhou, Y, Shen J, Wu, Z, Liu, G, Li, PW \& Tang, Y 2012, 'admetSAR: A comprehensive source and free tool for assessment of chemical ADMET properties', Journal of Chemical Information Modeling, vol. 52, no. 11, pp. 3099-3105.

Cheng, K, Qing-Zhong, Z, Qian, Y, Shi, L, Zhao, J \& Zhu, H 2009, 'Synthesis, antibacterial activities and molecular docking studies of peptide and Schiff bases as targeted antibiotics', Bioorganic \& Medicinal Chemistry, vol. 17, pp. no. $23,7861-7871$.

Daina, A, Olivier, M \& Zoete, M 2017, 'SwissADME: a free web tool to evaluate pharmacokinetics, drug-likeness and medicinal chemistry friendliness of small molecules', Scientific Reports, vol. 7, pp. 42717.

de Haan, CAM, Lili, K, Masters, PS, Vennema, H \& Rottier, PJM 1998, 'Coronavirus particle assembly: primary structure requirements of the membrane protein', Journal of Virology, vol. 72, pp. 6838-6850.

Delano, WL 2002, 'The PyMOL molecular graphics system', De-Lano Scientific, San Carlos, CA, USA.

Eliasson, B, Bjornsson, E, Urbanavicius, V, Andersson, H, Fowelin, J, Attvall, S, Abrahamsson, H \& Smith, U 1995, 'Hyperinsulinaemia impairs gastrointestinal motility and slows carbohydrate absorption', Diabetologia, vol. 38, pp. 79-85.

Glock, GE \& Patricia, M 1954, 'Levels of enzymes of the direct oxidative pathway of carbohydrate metabolism in mammalian tissues and tumours', Biochemical Journal, vol. 56, pp. 171. 
Guex, N \& Peitsch, MC 1997, 'SWISS-MODEL and the Swiss-PdbViewer: an environment for comparative protein modeling', Electrophoresis, vol. 18, pp. 2714-2723.

Guillén, D, Sergio, S \& Rodríguez-Sanoja, R 2010, 'Carbohydrate-binding domains: multiplicity of biological roles', Applied Microbiology and Biotechnology, vol. 85, pp. 1241-1249.

Guterres, H \& Wonpil, I 2020, 'Improving protein-ligand docking results with high-throughput molecular dynamics simulations, Journal of Chemical Information and Modeling, vol. 6o, pp. 2189-2198.

Hartinger, CG, Alexey, NA, Ashraf, MS, Dyson, PJ \& Keppler, BK 2008, 'Carbohydrate-metal complexes and their potential as anticancer agents', Current Medicinal Chemistry, vol. 15, pp. 2574-2591.

Hemre, GI, Mommsen, TP \& Krogdahl, A 2002, 'Carbohydrates in fish nutrition: effects on growth, glucose metabolism and hepatic enzymes', Aquaculture Nutrition, vol. 8, pp. 175-194.

Hermann, T \& Eric, W 1999, 'Docking of cationic antibiotics to negatively charged pockets in RNA folds', Journal of Medicinal Chemistry, vol. 42, pp. 1250-1261.

Hoever, G, Lidia, B, Michaelis, M, Kondratenko, R, Baltina, L, Tolstikov, GA, Doerr, HW \& Cinatl, J 2005, 'Antiviral activity of glycyrrhizic acid derivatives against SARScoronavirus', Journal of Medicinal Chemistry, vol. 48, pp. 1256-1259.

Hongbin, Y, Chaofeng, L, Lixia, S, Li, J, Cai, Y, Wang, Z, Li, W, Liu, G \& Tang, Y 2018, 'admetSAR 2.0: web-service for prediction and optimization of chemical ADMET properties', Bioinformatics, vol. 35, pp. 1067-1069.

Hornig, H, Paul, W \& Lührmann, R 1987, 'Decoding at the ribosomal A site: antibiotics, misreading and energy of aminoacyl-tRNA binding', Biochimie, vol. 69, pp. 803813.

Inc, AS 2013, 'Discovery Studio Modeling Environment', release 4.0.

Islam, MJ, Ajoy, K, Sunanda, P \& Nuruzzaman, SM 2020, 'The activity of alkyl groups in morpholinium cation on chemical reactivity, and biological properties of morpholinium tetrafluroborate ionic liquid using the DFT method', Chemical Methodologies, vol. 4, pp. 130-142.

Kaszyńska, J, Lapinski, A, Bielejewski, M, Luboradzki, R \& Tritt-Goc, J 2012, 'On the relation between the solvent parameters and the physical properties of methyl-4,6-Obenzylidene- $\alpha$-d-glucopyranoside organogels', Tetrahedron, vol. 68, pp. 3803-3810.
Kawsar, SMA, Hosen, MA, Fujii, Y \& Ozeki, Y 2020, 'Thermochemical, DFT, molecular docking and pharmacokinetic studies of methyl $\beta$-D-galactopyranoside esters', Journal of Computational Chemistry \& Molecular Modeling, vol. 4, no. 4, pp. 452-462.

Kawsar, SMA \& Hosen, MA 2020, 'An optimization and pharmacokinetic studies of some thymidine derivatives', Turkish Computational and Theoretical Chemistry, vol. 4, no. 2, pp. 59-66.

Kawsar, SMA, Faruk, MO, Rahman, MS, Fujii, Y \& Ozeki, Y 2014, 'Regioselective synthesis, characterization, and antimicrobial activities of some new monosaccharide derivatives', Scientia Pharmaceutica, vol. 82, pp. 1-20.

Kawsar, SMA, Kabir, AKMS, Bhuiyan, MMR, Ferdous, J \& Rahman, MS 2013, 'Synthesis, characterization and microbial screening of some new methyl 4,6-O-(4methoxybenzylidene)- $\alpha$-D-glucopyranoside derivatives', Journal of Bangladesh Academy of Sciences, vol. 37, pp. $145-158$.

Kitov, PI, Joanna, SM, Mulvey, G, Armstrong, GD, Ling, H, Pannu, NS, Read, JR \& Bundle, DR 2000, 'Shiga-like toxins are neutralized by tailored multivalent carbohydrate ligands', Nature, vol. 403, pp. 669-672.

Kobata, A 1993, 'Glycobiology: an expanding research area in carbohydrate chemistry', Accounts of Chemical Research, vol. 26, pp. 19-324.

Kondratenko, RM, Baltina, LA, Mustafina, SR, Vasil'eva, EV, Pompei, R, Deidda, D, Plyasunova, OA, Pokrovskii, AG \& Tolstikov, GA 2004, 'The synthesis and Antiviral activity of glycyrrhizic Acid conjugates with $\alpha-\mathrm{D}-$ Glucosamine and some glycosylamines', Russian Journal of Bioorganic Chemistry, vol. 3o, pp. 275-282

Kumer, A \& Khan, MW 2021, 'The effect of alkyl chain and electronegative atoms in anion on biological activity of anilinium carboxylate bioactive ionic liquids and computational approaches by DFT functional and molecular docking', Heliyon, vol. 7, pp. e07509.

Kumer, A \& Khan, MW 2021, 'Synthesis, characterization, antimicrobial activity and computational exploirations of ortho toludinium carboxylate ionic liquids', Journal of Molecular Structure, vol. 1245, pp. 131087.

Lee, YC \& Lee, RT 1995, 'Carbohydrate-protein interactions: basis of glycobiology', Accounts of Chemical Research, vol. 28, pp. 321-327.

Lee, DJ, Holly, OD, Routier, FH, Tiralongo, J \& Haselhorst, $\mathrm{T}$ 2019, 'Glycobiology of human fungal pathogens: New avenues for drug development', Cells, vol. 8, pp. 1348. 
Lennard-Jones, JE, Fletcher, J \& Shaw, DG, 1968, 'Effect of different foods on the acidity of the gastric contents in patients with duodental ulcer. 3. Effect of altering the proportions of protein and carbohydrate', Gut, vol. 9, pp. 177-182.

Li, J, Liang, X, Zhou, B, Chen, X, Xie, P, Jiang, H, Jiang, Z, Yang, $Z$ \& $\quad$ Pan, $X \quad$ 2019, '(+)-pinoresinol-O- $\beta$-D-glucopyranoside from Eucommia ulmoides Oliver and its anti-inflammatory and antiviral effects against influenza A ( $\mathrm{H} 1 \mathrm{~N} 1)$ virus infection', Molecular Medicine Reports, vol. 19, pp. 563-572.

Lipinski, CA, Lombardo, F, Dominy, BW \& Feeney, PJ 2001, 'Experimental and computational approaches to estimate solubility and permeability in drug discovery and development', Advance Drug Delivery Reviews, vol. 46, pp. $3^{-25 .}$

Liu, JX, Ying, Z, Hu, QP, Li, J, Li, Y, Wu, Q, Wu, J, Lai, X, Zhang, $\mathrm{Z} \& \mathrm{Li}, \mathrm{G}$ 2017, 'Anti-inflammatory effects of rosmarinic acid-4-O- $\beta$-D-glucoside in reducing acute lung injury in mice infected with influenza virus', Antiviral Research, vol. 144, pp. 34-43.

Liu, K \& Kokubo H 2017, 'Exploring the stability of ligand binding modes to proteins by molecular dynamics simulations: a cross-docking study', Journal of Chemical Information and Modeling, vol. 57, pp. 2514-2522.

Maowa, J, Hosen, MA, Alam, A, Rana, KM, Fujii, Y, Ozeki, Y \& Kawsar, SMA 2021, 'Pharmacokinetics and molecular docking studies of uridine derivatives as SARS-COV-2 Mpro inhibitors', Physical Chemistry Research, vol. 9, no. 3, pp. 385-412.

Maowa, J, Alam, A, Rana, KM, Dey, S, Hosen, A, Fujii, Y, Hasan, I, Ozeki, Y \& Kawsar, SMA 2021, 'Synthesis, characterization, synergistic antimicrobial properties and molecular docking of sugar modified uridine derivatives', Ovidius University Annals of Chemistry, vol. 32, no. 1, pp. 6-21.

Meegalla, RL, Jeffrey, BT \& Cheng, D 2002, 'Concerted elevation of acyl-coenzyme A: diacylglycerol acyltransferase (DGAT) activity through independent stimulation of mRNA expression of DGAT1 and DGAT2 by carbohydrate and insulin', Biochemical and Biophysical Research Communications, vol. 298, pp. 317-323.

Mirajul, MI, Arifuzzaman, M, Monjur, MR, Atiar, MR \& Kawsar, SMA 2019, 'Novel methyl 4,6-O-benzylidene- $\alpha-D-$ glucopyranoside derivatives: synthesis, structural characterization and evaluation of antibacterial activities',
Hacettepe Journal of Biology and Chemistry, vol. 47, pp. 153-164.

Miura, TA, Emily, TA, \& Oko, L, Bielefeldt-Ohmann, H, Weiss, SR, Beauchemin, N \& Holmes, KV 2008, 'The spike glycoprotein of murine coronavirus MHV-JHM mediates receptor-independent infection and spread in the central nervous systems of Ceacam1a-/- mice', Journal of Virology, vol. 82, pp. 755-776.

Mousavizadeh, L \& Sorayya, G 2021, 'Genotype and phenotype of COVID-19: Their roles in pathogenesis', Journal of Microbiology, Immunology and Infection, vol. 54, pp. 159-163.

Nakamura, M 2008, 'Cell Lines for Glycobiology, in Experimental Glycoscience', ed: Springer, pp. 403.

Nath, A \& Kumer, A 2021, 'Investigating the binding affinity, molecular dynamics, and ADMET properties of 2, 3dihydrobenzofuran derivatives as an inhibitor of fungi, bacteria, and virus protein', Beni-Suef University Journal of Basic and Applied Sciences, vol. 10, pp. 1-13.

Nath, A, Kumer \& A, Khan, MW 2020, 'Synthesis, computational and molecular docking study of some 2, 3dihydrobenzofuran and its derivatives', Journal of Molecular Structure, vol. 1224, pp. 129-225.

Niu, X, Yu, W, Li, W, Mu, Q, Li , H, Yao, H \& Zhang, H 2015, 'Protective effects of Isofraxidin against lipopolysaccharide-induced acute lung injury in mice', International Immunopharmacology, vol. 24, pp. 432-439. Nuruzzaman, SM, Ajoy, K, Sunanda, P \& Afroza, Z 2019, 'The theoretical prediction of thermophysical properties, HOMO, LUMO, QSAR and biological indics of cannabinoids (CBD) and tetrahhdrocannabinol (THC) by computational chemistry', Advanced Journal of Chemistry-Section A, vol. 2, pp. 190-202.

Ogundajo, AL, Lateef, AD \& Ashafa, AO 2018, 'Medicinal properties of Ocotea bullata stem bark extracts: phytochemical constituents, antioxidant and antiinflammatory activity, cytotoxicity and inhibition of carbohydrate-metabolizing enzymes', Journal of Integrative Medicine, vol. 16, pp. 132-140.

Pearson, RG 1986, 'Absolute electronegativity and hardness correlated with molecular orbital theory', Proceedings of the Naltural Academy of Sciences of the United States of America, vol. 83, no. 22, pp. 8440-8441.

Phillips, JC, Hardy, DJ \& Julio, DCM, 2020, 'Scalable molecular dynamics on CPU and GPU architectures with NAMD', Journal of Chemical Physics, vol. 153, pp. 044130. 
Pompei, R, Samuela, L \& Ingianni, A, 2009, 'Antiviral properties of glycyrrhizic acid and its semisynthetic derivatives', Mini Reviews in Medicinal Chemistry, vol. 9, pp. 996-1001.

Ramos, J 2020, 'Introducción a Materials Studio en la Investigación Química y Ciencias de los Materiales.

Rana, KM, Maowa, J, Alam, A, Dey, S, Hosen, A, Hasan, I, Fujii, Y, Ozeki, Y \& Kawsar, SMA 2021, 'In silico DFT study, molecular docking, and ADMET predictions of cytidine analogs with antimicrobial and anticancer properties', In Silico Pharmacology, vol. 9, pp. 1-24.

Ritter, TK \& Chi-Huey, W 2001, 'Carbohydrate-based antibiotics: a new approach to tackling the problem of resistance', Angewandte Chemie International Edition, vol. 4o, pp. 3508-3533.

Roberts, RW \& Crothers, DM 1992, 'Stability and properties of double and triple helices: dramatic effects of RNA or DNA backbone composition', Science, vol. 258, pp. 14631466.

Skjevik, AA, Benjamin, DM, Dickson, CJ, Teigen, K. Walker, RC \& Gould, IR 2015, 'All-atom lipid bilayer self-assembly with the AMBER and CHARMM lipid force fields', Chemical Communications, vol. 51, pp. 4402-4405.

Talarico, C, Silvia, G, Manelfi, C, Pedretti, A, Vistoli, G \& Beccari AR 2020, 'Combining molecular dynamics and docking simulations to develop targeted protocols for performing optimized virtual screening campaigns on the HTRPM8 channel', International Journal of Molecular Sciences, vol. 21, pp. 2265.

Trott, O \& Arthur, OJ 2010, 'AutoDock Vina: improving the speed and accuracy of docking with a new scoring function, efficient optimization, and multithreading', Journal of Computational Chemistry, vol. 31, pp. 455-461.

Van der Meer, FJUM, Haan, CAMD, Schuurman, NMP, Haijema, BJ, Peumans, WJ, Van Damme, EJM, Delputte, PL, Balzarini, J \& Egberink, HF 2007, 'Antiviral activity of carbohydrate-binding agents against Nidovirales in cell culture', Antiviral Research, vol. 76, pp. 21-29.

Weymouth-Wilson, AC 1997, 'The role of carbohydrates in biologically active natural products', Natural Product Reports, vol. 14, pp. 99-110.

Yasmin, F, Amin, MR, Hosen, MA, Bulbul, MZH, Dey, S \& Kawsar, SMA 2021, 'Monosaccharide derivatives: synthesis, antimicrobial, PASS, antiviral and molecular docking studies against SARS-CoV-2 Mpro inhibitors', Cellulose Chemistry and Technology, vol. 55, pp. 477-499.
Yurkovetskiy, L, Xue, W \& Pascal, KE 2020, 'Structural and functional analysis of the D614G SARS-CoV-2 spike protein variant', Cell, vol. 183, pp. 739-751.

Zeller, BL, Saleeb, FZ \& Ludescher, RD, 1998, 'Trends in development of porous carbohydrate food ingredients for use in flavor encapsulation', Trends in Food Science \& Technology, vol. 9, pp. 389-394.

Zhu, H, Yuanyuan, Z, Ye, G, Li, Z, Zhou, P \& Huang, C 2009, 'In vivo and in vitro antiviral activities of calycosin-7-O- $\beta$ D-glucopyranoside against coxsackie virus B3', Biological and Pharmaceutical Bulletin, vol. 32, pp. 68-73. 